\title{
MODERN ASSUMPTIONS OF THE AMERICAN BALLISTIC MISSILE DEFENCE SYSTEM AGAINST THE BACKGROUND OF HISTORICAL CONCEPTS AND PROGRAMMES
}

\author{
2Lt MSc Aleksandra MURAT-BORS \\ Faculty of Command and Naval Operations \\ Polish Naval Academy, Gdynia. Poland \\ murat.aleks@gmail.com
}

\begin{abstract}
The issue of missile defence has been present in American policy for over 70 years and is constantly subject to research and the search for new technologies. Nowadays, the proliferation of nuclear weapons and ballistic missiles, as well as the growing threat from the so-called "rogue states" have caused the inevitable development of the missile defence strategy. On the basis of historical programmes and the results of contemporary research, the concept of a Ballistic Missile Defence System was created. The system is based on the principles of indivisibility of the security of the Alliance and NATO solidarity, fair sharing of risk and burdens as well as taking on reasonable challenges. One of the components of the system is the European Phase Adaptive Approach, which was designed to protect American allies and resources in the European region from the growing rocket threat.

This paper analyses the genesis of ballistic missile defence and what its development tendencies are. The article contains a presentation of the essence of the US Ballistic Missile Defence System, as well as its history and suspended programmes. The concept of multilayered defence has been outlined, as have the technical details of the system's components and its location and operational status.
\end{abstract}

Keywords: security, missile defence, nuclear weapons, ballistic missile, NATO 


\section{Introduction}

The parallelism of the proliferation of nuclear weapons and development of missile technology mean that limited strategic rocket attacks might become one of the most important methods of asymmetric use of weapons of mass destruction. The more we look to the future for analysis, the more probable the threat becomes. In the strategic sense, there is no doubt that the strategy of defending against such threats cannot be limited only to deterrence by retaliatory strikes. However, there are questions as to whether the rocket attack of a terrorist organisation can be stopped in this way, and if so, where to address this counterstrike, and whether the threat of atomic retaliation is also an appropriate response to blackmail from the "rogue state" by launching a rocket attack using chemical or biological cargoes. For this reason, anti-missile defence is strategically attractive and up-to-date today. There is a strategic demand for it and there are technological possibilities to implement it. The result of these two trends is the inevitable development of the missile defence strategy system (Koziej 2007).

The purpose of the article is to demonstrate what ballistic missile defence is and what its development tendencies are, give a brief description of the US Ballistic Missile Defence System and its technical details, as well as describe its components. Therefore, the research issues are contained in the author's following questions: What is the purpose of Ballistic Missile Defenve System? What are the technical details of BMDS components? What is the future of this system going to be?

The methods used herein include an analysis of literature and the synthesis which allowed the research objectives to be achieved and the research issues to be resolved. The research also used analysis of sources (documents and legal acts), which led to the selection of relevant information. 


\section{The essence and purpose of the US Ballistic Missile Defence System}

The distribution and increase in the number of ballistic missiles poses a growing threat to the population and territory of NATO countries and the Alliance's military forces located in a large area of the globe. Many countries already have or are trying to produce or acquire ballistic missiles. Multiplication of these capabilities does not necessarily mean that there is a direct intention to attack NATO, but mainly that the Alliance is obliged to take this into account as part of its main collective defense mission. The system is based on the principles of indivisibility of the security of Alliance and NATO solidarity, fair sharing of risk and burdens as well as taking on reasonable challenges. It also takes into account the level of threat, affordability and technical feasibility, and is in line with the latest threat assessments agreed by the Alliance. If international efforts reduce the threat of ballistic missile proliferation, NATO will be able to adapt to the situation (North Atlantic Treaty Organisation 2016).

Missile defence can be defined as a set of forces, means and actions, the task of which is to prevent the enemy's ballistic missiles from reaching their goal. It is part of the air defensce aimed at repelling (preventing or minimising) air attack when the aggressor uses air assault means (including strategic aviation and ballistic missiles). Three phases can be distinguished in the operation of each missile defence system: (1) detection, (2) tracking and identification of objectives, and finally (3) intercepting and destroying a foreign rocket (or possibly pushing it away from the correct trajectory). An especially important role in it is played by interceptor rockets, notable for their very high acceleration and constant combat readiness (Encyklopedia Techniki Wojskowej 1978).

The task of the Ballistic Missile Defence System is to protect the US territory, their armed forces and allies, as well as their troops beyond their own borders against ballistic missile attacks on the part of, above all, the "rogue states", especially Iran or North Korea. It is about the so-called "new" countries that have weapons of mass destruction and their means of transmission, or strive to obtain such weapons. The US government sees the post-Cold War security environment as unstable and anarchic, and its unpredictability deepens the proliferation processes of atomic, biological and chemical weapons in many regions, especially 
in those where the "security vacuum" was created after the collapse of the Eastern Bloc (Kaczmarski 2004). The exact definition of the prospects for "rogue states" gaining intercontinental ballistic missiles is extremely difficult due to the lack of full and reliable information on the actual advancement of their nuclear and/or conventional means of transferring nuclear warheads. Undoubtedly, it can be said that entities such as Iran and North Korea are intensively working on rockets whose technical capability would enable them to hit any place in the world. For the United States, it is obvious that it is only a matter of time before these countries acquire their territorial capability, which in turn may pose a serious threat to US and even international security. Hence, it is necessary to create a system that can protect against these future threats rather than contemporary ones (Smith 2000).

The European Phased Adaptive Approach was designed to protect American allies and resources in the European region from the growing rocket threat. The Aegis systems in Europe are therefore designed and deployed to defend against ballistic missiles from the Middle East and are distinguished by their lack of technological capabilities to counteract threats coming from Russia. It is a purely defensive system aimed at combating threats from outside the Euro-Atlantic area (Wilkening 2005).

\section{The genesis of the ballistic missile defence systems}

The issue of missile defence has been present in American policy since the mid1940s, which was caused by the use during World War II of the first German V-2 ballistic missiles, which from 1944 terrorised the population of Great Britain (Scheffran 2007). Ballistic missiles did not change the outcome of the war; however, they had a significant impact on defence doctrines, arsenals and the security policy of those times. Already in the first days after the end of the war, a special operational group was established and tasked with preparing a report summarising the Allied methods for counteracting these missiles. In March 1946, the US Air Force began working on the Thumper and Wizard projects, of which only the latter was continued on a larger scale and brought moderate success (Ciastoń 2007). 
The growing tension between the USSR and the US in the 1950s caused the acceleration of President D.D. Eisenhower's anti-missile shield programme, which resulted in the Nike II project. Tens of thousands of attempts carried out under this programme have proved that it is possible to destroy a ballistic missile with another rocket of this type. The experiences from both this and previous projects were used to initiate the construction of the Nike-Zeus anti-ballistic missile in 1957. It was designed to be part of an integrated defence system that would include advanced capturing and tracking radars and battlefield communication devices. However, due to the lack of significant progress in research and the difficulty in developing a technology that allows for rapid detection and identification of an alien rocket, this programme was suspended in 1961.

The catalyst for the development of American work on the missile defence programme was sending the world's first artificial satellite, Sputnik 1 , into orbit by the Russians. The creation of an effective defence system against intercontinental missiles has become a priority for US security (Jankowski 2011). As an alternative to Nike-Zeus, the Defender programme was proposed in 1958. It was one of the more advanced projects that assumed an unconventional, far-sighted approach to possible problems. With the initiation of Defender, an Advanced Research Projects Agency was created, whose task was to identify new means that could be used to increase defence capabilities. The Defender project went far beyond the capabilities of Nike-Zeus and resulted in the analysis of all phases of ballistic missile defence. All capture concepts defined in this period were known as BAMBI. Despite unconventional and original solutions, the programme was suspended in 1968 due to difficulties in the development of some technical solutions (Dobrosielski 1973).

The dynamics of international relations led the world to the brink of a nuclear war. The Cuban crisis of October 1962 gave the United States a boost to create a new, improved and more robust system called Nike-X. The main change was abandoning the attempt to intercept the ballistic missile in its initial phase of flight for its destruction outside the atmosphere in the midcourse phase of the flight. The programme was quite advanced and technologically complex (Smith 2000). The dynamically changing geostrategic situation, including China's attempts to make atomic and thermonuclear bombs, as well as the development of Russia's missile defence programme, resulted in the need to build a more advanced 
anti-missile system. In this situation, a concept was proposed that assumed the creation of "thin missile defence" over large groups of people, assessing that there are no technical means capable of defending the entire US territory against the aggression of the PRC or the USSR. In 1967, the Nike-X programme was expanded as part of the new Sentinel project. Only a year later, the first major debate about the future of the anti-missile shield programme was initiated, and its main contribution was the campaign of President L. Johnson to change the nature of the system. Ultimately, the discussion remained in the background due to the Vietnam War, without bringing about any significant changes in the implementation of the programme. President Nixon taking office led to further changes in the US missile defence concept. In 1969, the programme was given the new name Safeguard and it was decided that as well as cities it would also protect silos with intercontinental rocket launchers and equipment as well as the command and communication systems (Hołdak 2007).

Parallel to the missile defence system development by the US and the USSR, negotiations on the reduction of the level of armaments continued. Both countries were concerned about the possibility of increasing the potential of the opponent, which would result in an increase in the rate of the arms race, as well as an increase in defence spending. The Soviet-American negotiations on the limitation of strategic armaments, initiated on November 17, 1969 in Helsinki, ended on May 26, 1972 with the signatures of L. Brezhnev and R. Nixon on the Anti-Ballistic Missile Treaty (a Treaty between the United States of America and the Union of Soviet Socialist Republics on the Limitation of Anti-Ballistic Missile Systems 1972). This system put an end to the dynamic development of anti-missile programmes, consequently causing the disappearance of this topic from the strategic debate for more than a decade. The strategic goal of the ABM contract was to ensure the certainty of mutual destruction in the event of the use of nuclear weapons by one of the parties. The possibility of surviving a nuclear attack through such a part of the offensive forces was assumed in order to be able to retaliate. It is recognised as a well-constructed mechanism for ensuring security through deterrence. Both parties benefited from the rights granted to them in the ABM system, building single missile defence systems - the US around 150 intercontinental missile launchers in North Dakota, and Russia around Moscow. However, while the US suspended its system, the Russians developed a shield around the capital and, to this day, it has operational status (Kaczmarski 2004). 
Significant progress in the development of Soviet missile technologies in the early 1980s caused serious concern among US military analysts. Opinions expressing the need to create an anti-missile system capable of providing defence for the United States have become more and more loud. With the presentation by President R. Reagan - in his most famous television speech of March 23, 1983 - of the programme for militarisation of space, the so-called Star Wars, the perception of the need for effective missile defence changed. The acceleration of the development of research on the creation of space missile systems, which would allow the enemy's missiles to be captured above the Earth's atmosphere, as well as at the place of their launch, took place. The construction of the shield was to replace the deterrence strategy, making the nuclear weapon useless. It was also supposed to be a kind of definitive "anti-defence", eliminating all the others (Kaczmarski 2004).

On April 18, 1983, work was initiated on two secret reports: the Defensive Technologies Study, which aimed at technical assessment of the possibility of building an anti-missile shield and the Future Security Strategy Study, aimed at indicating the political implications of its creation. The first of the documents proposed the creation of multilayered missile defence in applications. The main conclusion of the second report was the idea that even an imperfect BMD system would contribute to strengthening nuclear deterrence (Hołdak 2007). On this basis, a programme was created under the codename Strategic Defense Initiative in 1984. Due to the continuous existence of the ABM system, it was initially only a research project. The transition to the implementation phase only took place in 1987, being at the same time a violation of the ABM Treaty. In 1985, the Strategic Defense Initiative Organisation presented the first version of the missile defence system: it had to have multi-shell architecture and have the ability to defend 3,500 goals. Hundreds of small satellites detecting the start of enemy missiles, sensors tracking the trajectory of their flight, and the interceptor missile launcher were planned to be deployed in space and on land. The enemy missiles were to be shot down with Directed Energy Weapons such as high-power lasers or high-energy particle accelerators. However, two years later, the first stage of implementation of the SDI was corrected, in which the DEW were replaced by missiles destroying incoming ballistic missiles by direct collision (Smith 2000). 
President R. Reagan, applying such great importance to the SDI project, contributed to the consolidation of the concept of anti-missile defence in American society. Despite numerous corrections, the Strategic Defense Initiative became the foundation for the construction of the new National Missile Defence system.

With the disintegration of the Eastern Bloc, the Strategic Defence Initiative programme lost its significance and was closed in 1989, only 5 years since its launch. The US no longer had to strive to gain a strategic advantage over the enemy from the east and be afraid of a massive attack of missile ballistic intercontinental missiles. However, the reduction of the threat from Russian intercontinental missiles with nuclear warheads was accompanied by the proliferation of smaller range missiles, primarily tactical and tactical-operational, capable of transferring both conventional and mass destruction. Despite the reduction of the threat from Russia, the threat of using the missile potential of other countries to attack the US territory or US troops deployed outside the North American continent has not ceased. This was especially true of countries that revealed their great-power ambitions in the new geostrategic environment. Moreover, the chaos caused by the collapse of the USSR has intensified the fear of it using its nuclear forces in an unauthorised and uncontrolled manner. It has become clear that a complete departure from plans to create a missile system was a mistake.

For this reason, the concept of defence against ballistic missiles on a smaller than intercontinental range within the theatre of warfare emerged. It should also be borne in mind that the technological (and thus economic) development of the United States, initiated during the Star Wars, allowed for the materialisation of a significant part of Reagan's BMD concept - the transition from the research programme to the implementation of the system (Hołdak 2007). In 1991, the GPALS project was initiated, the aim of which was to neutralise ballistic missiles regardless of where they were launched. This programme was to replace the first phase of the SDI project, while limiting the size - it was to consist of about a thousand interceptor shells spaced out in outer space and 750 missiles located on land. The entire target was to be formed by three subsystems:

- National Missile Defence sea and land based relegation,

- Missile Defence of the Theatre of Action (TMD), based on land,

- Global Missile Defence, based in space. 
Implementation of the entire GPALS project proved impossible due to the coming to power Clinton in 1983. Democrats' strong emphasis on maintaining the existing arms control regime, especially the inviolability of the ABM treaty, led from the concept of building NMD for TMD. Following a coordinated review of the US defence requirements (Bottom-Up Review) on May 13, 1993, the Strategic Organisation of the Defence Initiative was renamed the Ballistic Missile Defence Organisation. Emphasis was placed on the TMD component, thus condemning the NMD to remain only a research programme.

At the same time, the programme was directed so that in the event of a real threat of rocket attack, the created defence system could be quickly deployed and put into a state of combat readiness. Thus, at the end of 1993, the NMD changed its name to the Technology Readiness Programme. Ultimately, the NMD did not just become a research programme thanks to the Republican majority in congress in 1994. They proposed an extension of work on missile defence and negotiations with Russia regarding the introduction of amendments to the ABM system.

A new stage in the history of the NMD project was begun on February 16, 1996 by the US secretary of defence, W.J. Perry, which initiated the 3 Plus 3 programme. It was intended to finish the initial stage of system development in 1999 and to introduce it in the testing phase. Then, in 2000, a decision was made to deploy it. Then came the concept of defending US territory against ballistic missile attacks from "rogue states" (in the late 1990s, Afghanistan, Iran, Iraq, Libya and North Korea were recognised as such). At the same time, an office was established for the coordination of the NMD programme under BMD (the so-called Joint Programme Office). Unfortunately, the Report of the Commission to Assess the Ballistic Missile Threat to the United States by Gen. L. Welch panel published in 1998 showed that the system was not prepared for full dislocation in 2003, especially due to the lack of proper tests. Therefore, it was decided to postpone the implementation of this stage to 2005.

Meanwhile, missile defence gained new supporters, among other things as a result of the conclusions presented on July 15, 1998, the so-called Rumsfeld report on the threat level of the United States and their armed forces from ballistic missile attacks. The report considered such a threat to be too big, while stressing that it would grow (Pacholski 2003). This report opened the way for Americans to 
start unlimited work on the missile system, including treating it in the sphere of defence planning as an integrated whole, a so-called system of the systems.

The new president of the USA G.W. Bush, in office from January 2001, returned to intensive work on the shield concept. The main element of his policy was the assumption that the US should use its economic, military and political potential to ensure maximum security - even at the cost of violating international law. G. W. Bush introduced significant changes to the concept of the entire system and at the same time changed its name to Missile Defence (MD). Removing the adjective "national" indicated that the concept was also for the American allies (Turczyński 2012). In a speech delivered on May 1, 2001, President G.W. Bush said, among other things, that despite the end of the Cold War, the world still remains unsecure and unpredictable. Ballistic missiles and weapons of mass destruction had got into the hands of the least responsible countries in the world. This weapon was intended primarily to deter neighbouring countries and to stop the US and other responsible states from helping their allies and friends in strategic parts of the world. Dictators such as S. Hussein did not care about the populations of their countries and deterrence is not enough for them. That is why the US needed a new concept of deterrence, based on offensive and defensive forces. In addition, effective defence could reduce the attractiveness of ballistic missiles (Remarks by the President to Students and Faculty at National Defence University, 2001). The MD programme was to build a multilayered and multi-element missile defence system consisting of a network of terrestrial and space sensors, command posts and control centres and fire subsystems destroying ballistic missiles in each phase of their flight.

MD was to consist of the following subsystems: command; sensors, as well as the Boost Defence Segment with spacecraft and on-shore Kinetic Energy Interceptors and Airborne Lasers, Midcourse Defence Segment with a Groundbased Midcourse Defence and sea Aegis BMD, and a Terminal Defence Segment with mobile air defense missiles.

The attacks of September 11, 2001, became a catalyst for the development of the anti-missile shield. Changing the character of the opponent caused a return to the idea of anti-ballistic defence on the largest scale since the times of the SDI. In response to the terrorist threat, on December 13, 2001, the US withdrew from the $\mathrm{ABM}$ treaty, thanks to which it was possible to develop and implement a missile 
defence programme. The logical consequence of the change in American policy was the establishment of a new institution responsible for research, development and implementation of systems for combating hostile missiles. This institution was called the Missile Defence Agency. Officially, it was created on January 4, 2002 , and its statutory goal was to create a system that allowed the defence of US territory, armed forces abroad and allies against ballistic missile attacks of all ranges, in each phase of their flight. This was to be achieved through the construction, testing and commissioning of an integrated, multilayered BMD system (Turczyński 2012).

On September 17, 2002, a new National Security Strategy of the United States of America was announced, which stated that the deterrence strategy, based only on the threat of a retaliatory attack, could not stop the leaders of "rogue states" from taking the first step and using ballistic missiles. Hence, it was necessary for the US government to adopt the Doctrine of Preemption as an instrument that could stop these states and terrorists from threats of using or using weapons of mass destruction against America or its allies. Thanks to the earlier programmes, the first stationary and marine MD elements in the form of sensors were launched in 2004-2005. From then on, MD was to become an effective response to such a threat, and at the same time a permanent element of the defence strategy and martial art of the United States (Kwasek 2016). The structure ultimately called the shield began to gradually transform into reality.

The financial crisis in the autumn of 2008 and the takeover of power by B. Obama caused the slowdown of work on the anti-missile shield. In 2009, the new administration withdrew from the KEI project due to financial and construction problems, and successively resigned from subsequent systems to ensure defence in the boost phase. Finally, abandoning the entire G.W. Bush programme was announced on September 17, 2009. The system was officially announced and its construction postponed until more modern anti-missile technology was created. At the same time, an EPAA programme was launched to cover Europe's area of missile defence.

In 2013, the administration of B. Obama admitted that its policy towards the BMD system was wrong. In March of the same year, the then defence secretary C. Hagel announced that the United States would strengthen the GMD component in Alaska and California. The change in policy was due to the recognition that 
the long-range missile threat from Iran and North Korea had not diminished, as the B. Obama administration argued, and was actually increasing. A decision was also made on the deployment of additional BMD sensors and components, including the introduction of Terminal High Altitude Area Defence Theatre on Guam and South Korea, as well as two advanced radars in Japan.

The current US president D. Trump, who took office in 2017, announced the development of a state-of-the-art missile defence system that would protect the US from attack by Iran and North Korea in his inaugural speech. However, he did not provide any details on how it would improve in relation to the existing ones, but more and more money is being spent on improving the BMD system (The White House 2018).

\section{Expansion of the anti-missile shield for Europe}

When analysing the goals set for the MD system, it is worth paying attention to their twofold nature - propaganda and real. The justification for the need to expand the shield, and above all its location outside the continental United States, required the creation of such a vision that would be attractive to US allies, mainly in Europe (Hildreth 2009). The European continent has become an extremely important element of the "new" MD. Already in 2001, it was decided to extend the concept of US missile defence to allied states, and after the expiry of the 2002 ABM treaty, it was possible to start an unlimited international missile defence system project for the new area (Heurlin 2005).

In 2002, the NATO Alliance summit in Prague initiated a feasibility study of the allied system, and five years later the North Atlantic Council decided to proceed with the construction of an allied missile shield, which was approved at the summit in Bucharest the following year. At the same time, in 2003-2004, the governments of Denmark and Great Britain agreed to modernise and incorporate radiolocation stations in their countries into BMDS. For the efficient operation of the MD and the ability to intercept ballistic missiles, it was necessary to install two more system components in Europe: Ground Based/X-Band Radar and interceptor shells (40-50 pieces), constituting the GBD segment. Analyses have shown that the areas where these installations should be placed are Bulgaria, the 
Czech Republic, Hungary, Italy, Poland, Slovenia and the United Kingdom and the final date for the system's launch was set for 2013. The stationary elements planned for deployment in Europe were to be part of the terrestrial component used to capture and destroy ballistic missiles in the midcourse phase of the flight (Kwasek 2016).

The final decision on the distribution of MD elements was made by America in 2006. It was proposed to place a GBR detector in the Czech Republic, and a Ground Based Interceptor in Poland. In 2007, the US officially proposed to the Czech Republic and Poland the construction of certain elements of the antimissile shield in their area. The Czech element was to be found in Brda, and the Polish in Redzikowo near Słupsk. Permanent bases in the Czech Republic and Poland were to be the third facility with Alaska (GBI base at Fort Greely and SeaBased X-Band Radar located on a platform offshore) and California (Vanderberg base with GBI and mobile station Forward Based X-Band Radar) for locating missiles and a guiding radar station. In 2008, a Polish-American agreement on the construction of elements of the anti-missile shield in Redzikowo was signed (Raabe 2008).

However, in 2009, before the construction of these elements began, the US administration withdrew from plans to deploy heavy GBI capable of fighting longrange and intercontinental missiles, for systems with missiles destroying medium and short range missiles, based on existing and tested technologies and placing greater emphasis on mobile systems that would be able to quickly transfer to areas of danger. Thus, the system that was supposed to be created on the European continent, from the component developed in America, was somehow separated. Ultimately, it was decided that the new EPAA system for Europe's missile defence would be based on the Aegis marine system with evolutionary SM-3 missiles. The programme was divided into four phases, where ships with Aegis systems and subsequent versions of SM-3 and land modules were to be gradually deployed. Ultimately, by 2020 , a system was to be created and its capabilities were to be able to combat medium and long-range ballistic missiles.

At the summit in Lisbon in November 2010, NATO leaders decided to develop their territorial missile defence capability. It was assumed then that the EPAA would be integrated with the national components of the missile defence of the member states developed within the framework of the allied Active Layered 
Theater Ballistic Missile Defence. From among several proposed locations for the land component locations, Poland, Romania and Turkey were finally chosen. Such location of SM-3 missiles resulted from the necessity to achieve very short system response times. The whole undertaking of the construction of the EPAA system was divided into four stages:

- Stage I (2011) - deployment of American ships with the Aegis BMD 3.6.1 missile system with SM-3 Block IA missiles in the Mediterranean Sea;

- Stage II (2015) - launch of the anti-missile base in Romania with the Aegis Ashore MDS 4.0.1 system with SM-3 Block IB missiles;

- Stage III (2018) - launch of the missile defence system in Poland with the Aegis Ashore MDS 5.0 system with SM-3 Block IIA missiles;

- Stage IV (2020) - deployment in anti-missile systems and naval systems of Aegis BMD 5.1/MDS 5.1 with SM-3 Block IIB missiles.

In May 2012, at the Chicago summit, NATO leaders announced the end of Phase I consisting of radar in Turkey, a command centre in Germany, and Aegis BMD deployed on board. Thus, the maximum coverage of available means of defence of the population, territory and NATO forces in Southern Europe against a limited missile attack would be ensured (Arms Control Association 2017).

Changes in geopolitical conditions, but also technical problems and the expected excessive increase in costs meant that the American administration decided in 2013 to cancel the fourth phase of the EPPA and the project of the SM-3 Block IIB anti-attack ended at the construction stage. Halting the last phase of the project also directly concerned installations built under the two previous phases, i.e. both Aegis Ashore MDS systems. The subject of the last stage of the development of the EPAA was to be the conversion of the base in Redzikowo to the SM-3 Block IIB missile in 2022. Although the change of plans of the US-built missile defence system in Europe was dictated by the desire to guarantee the most effective defence and protection of its territory, troops stationed outside the country and American allies in the face of mounting threats from North Korea, this decision was the result of many other factors. It was also affected by budget constraints from 2012 and the resulting cuts in defence spending, the desire to boost cooperation with Russia, as well as technological problems related to the development of the SM-3 Block IIB missile. In exchange for abandoning the fourth phase of the EPAA, it was proposed to place ships with new SM-3 Block IIA missiles in the North Sea 
or to replace it with a missile base on the east coast of the USA. Finally, in March 2013, it was announced that the US Department of Defence's modification of the missile defense system had enabled the last stage of the EPAA to be abandoned and the shield on the west coast of the United States, Alaska and Japan strengthened (Kwasek 2016).

The first aviation test of the Aegis Ashore system was successfully carried out in May 2014 at the Pacific Missile Range Facility, in Kauai, Hawaii. The tests in PMRF guaranteed that the architecture of the Aegis Ashore software and hardware in Romania had been tested in combat conditions. Then, in November 2014, MDA successfully performed the Aegis BMD aerospace test, including Aegis Ashore components. The system detected, followed and intercepted two self-tracking missiles and a short-range ballistic missile (Missile Defence Advocacy Alliance 2018a).

The preparation of the infrastructure for the assembly of the Aegis Ashore MDS system was started in Romania in October 2013. Inauguration of the construction took place with the participation of the President of Romania T. Băsescu and undersecretary of defence J. Miller. The finished Aegis Ashore BMDS was assembled and tested in the United States in New Jersey, then disassembled and transported to Romania. The entity named Naval Support Facility Deveselu is responsible for the service of the base, which started operation in October 2014. At the same time, at Lockheed Martin Corp., the Maritime System and Sensors Main Plant in Moorestown, New Jersey assembled the system itself and performed functional tests. In May 2016, NATO announced the operational side of Romanian Aegis Ashore as part of Phase II of the EPAA. In July 2016, the Initial Operational Capability of the NATO missile defence system was announced at the summit in Warsaw and full operational capacity was being sought (LaGrone 2016).

The implementation of the third and final phase of the EPAA, i.e. the construction of the base in Poland, was officially launched in May 2016, although the construction of the system had already been started, while the American side of the preliminary field research had been running for two years. The inauguration of the investment was attended by President of the Republic of Poland A. Duda, Minister of National Defence A. Macierewicz, Minister of Foreign Affairs W. Waszczykowski, and Deputy Secretary of Defence of the US R. Work. Aegis Ashore from Redzikowo, in addition to the newer ones developed jointly with the Japanese Mitsubishi 
Heavy Industries group, SM-3 Block IIA missiles will receive an improved 9.B2 operating system with BMD 5.1 software. In accordance with the provisions of the Armed Forces Development Programme currently being implemented for 20132022 and the Polish-American agreement on the construction of Aegis Ashore MDS in 2016, the Battalion of Defence of the Ballistic Missile Defence System Base (Battalion of Protection of the Redzikowo Base) was formed. Ultimately, the base in Redzikowo will be served by about 150 people of the US Navy staff, which today has about 70 sailors. The initial operational readiness of the ballistic missile base at Redzikowo and its integration with other components of the American EPAA programme is to take place in December 2018.

In March 2018, the head of MDA General Lieutenant Samuel Greaves informed the US Senate about the expected delay in contagion of operational readiness by the owner of the Aegis system in Redzikowo. Most likely, it will not be ready before 2020. The American commander, however, did not disclose more details about the causes of the expected delays. Officially, MDA, in a written statement from its head before the Senate Committee of Armed Services, indicated the unsatisfactory pace of building the base. Currently, it is planned for 2020 .

\section{Technical aspects of the Ballistic Missile Defence System}

The BMD system is designed for many years of development, it uses all the technologies that can be applied today and the perspectives for the future. Based on the multilayered approach, it uses land and sea based current and future measures to combat ballistic missiles capable of carrying weapons of mass destruction. Compared to all previous US missile defence concepts, this project is the most comprehensive, as it includes three levels of missile defence: tactical, operational and strategic. According to the intentions of the United States and resulting from the current shape and plans of the system for the future of technical capabilities, BMD is to include North American ballistic protection, the territory of European NATO members, as well as Israel, Japan and South Korea.

A ballistic missile is a type of projectile whose most important structural features are a flight on a parabolic ballistic curve, achieved thanks to motor drive only in the first part of the road and having a control and guidance system. At the 
climb stage, the flight takes place thanks to propulsion from one or more rocket engines, and further flight stages take place thanks to the use of energy given to the missile in the engine phase and thanks to the gravitational force of the Earth. The use of ballistic missiles is based on transferring to the target of a conventional warhead or mass destruction (Carter and Schwartz 1984).

Rocket ballistic missiles are categorised depending on their range, understood as the maximum distance from the launch point to the target, measured in a straight line across the earth's surface. The most commonly used is the American division, distinguishing four basic groups of missiles ranked by range, and one class of missiles fired from submarines:

- Intercontinental Ballistic Missiles: over 5,500 km;

- Intermediate-Range Ballistic Missiles: 3000 to 5500 km;

- Medium-Range Ballistic Missiles:: 1000 to 3000 km;

- Short-Range Ballistic Missile: up to $1000 \mathrm{~km}$, within this group of missiles, sometimes Battlefield Short-Range Ballistic Missiles are extracted with a range of up to $150 \mathrm{~km}$.

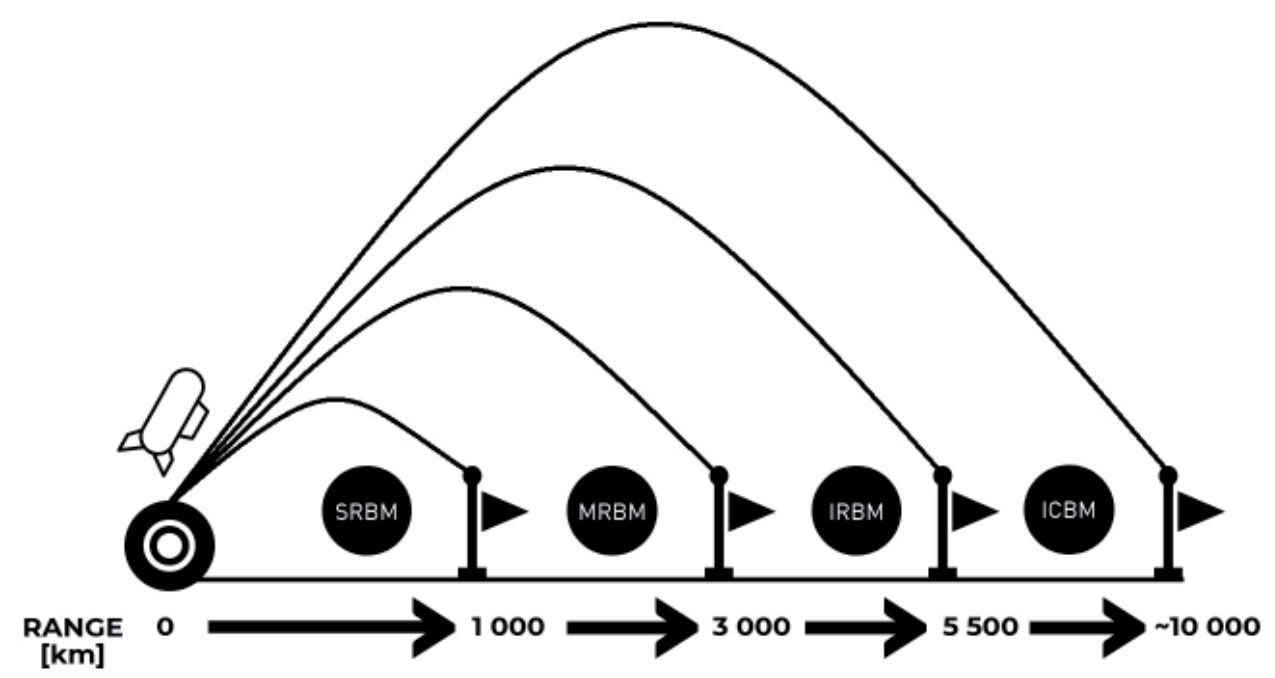

Source: own elaboration

Figure 1. Comparison of ballistic missile ranges 
In this division, there is also an additional category - Submarine-launched Ballistic Missile. Due to their coverage, they should be classified as ICBM; however, due to the special role of these missiles, resulting from the very high survivability of the opponent's first hit and the concealed nature of their transfer - including near the borders of the state that is their target (and the possibility of the first, incapacitating atomic strike), they are classified as a separate group. The distances available for each class refer to the maximum range of missiles, which can also be used to attack shorter distances (Global Security 2017). Missile defence technology developed, tested and implemented by the United States aims to counter ballistic missiles of all categories.

The basic principle and condition of the ballistic missile's operation is to give it such a speed that it will be able to overcome earthly attraction and exit into the highest atmosphere, less from the first space velocity, which is $7.91 \mathrm{~km} / \mathrm{s}$ for the Earth. Achieving this by projecting or crossing the first cosmic velocity would cause it to enter into orbit around the planet and to circumnavigate the planet instead of gravity pulling it towards the target. The ballistic missile moves on a parabolic ballistic curve peaking in the highest, exospheric layer of the Earth's atmosphere, where its flight consists of three phases: the boost, the midcourse and the terminal one.

The boost phase is part of the ballistic missile flight during which the supporting engines operate until the projectile reaches the maximum speed. This phase may last from 3 to 4 minutes in the case of a solid fuel rocket (shorter in the case of a liquid fuel rocket), the height at the end of this phase is $150-200 \mathrm{~km}$, and the typical firing speed is $7 \mathrm{~km} / \mathrm{s}$. The midcourse phase lasts for the majority of the ballistic missile flight time, from 3-4 minutes to almost an hour (depending on the range of the projectile). When the rocket fuel is exhausted (or the engines are switched off - the so-called zeroing of the thrust), a missile or separated heads (so-called cloud) move with the force of inertia due to the speed given to them in the boost phase. The terminal phase of the projectile's trajectory begins when the charge begins to return to the atmosphere again. The power of gravity overcomes the decreasing inertia force by directing the projectile towards the earth and its purpose. The duration of this phase depends on both the range of the projectile and the technical extent of the projectile in terms of its ability to penetrate the anti-ballistic defence. In this phase, the missile, or its head, returns to the dense 
atmosphere and overcoming the resistance and temperature that it sets, makes the final move to the target, attacking it with a conventional charge or mass destruction (United States of America Congress 2002).

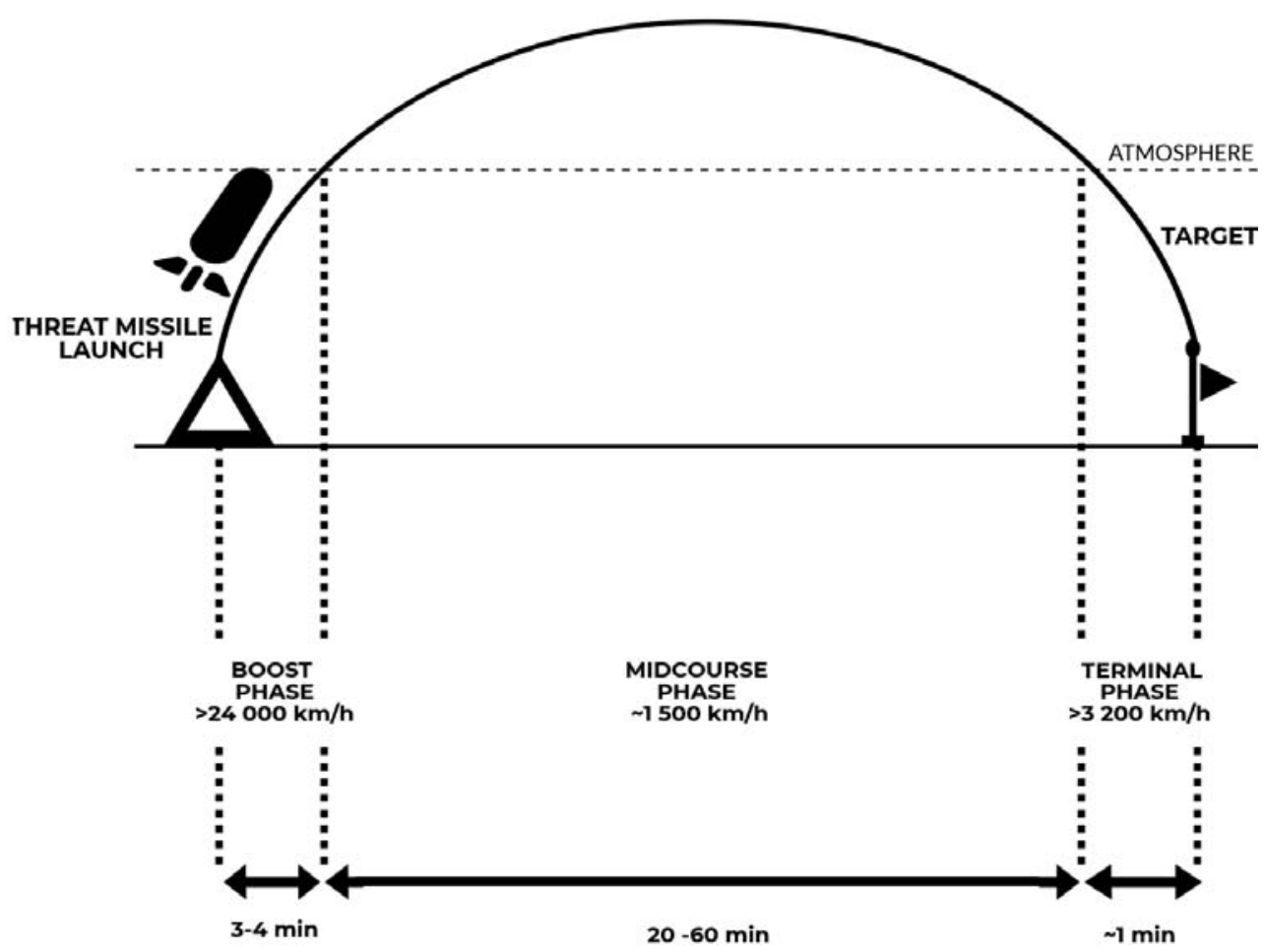

Source: own elaboration.

Figure 2. The phases of the ballistic missile flight

The BMD project is based on the assumption that enemy rockets will be destroyed regardless of the launch or flight phase. Therefore, it is based on a ballistic missile system composed of three layers, each of which is responsible for the destruction of the target in the next phase of the flight: the boost, midcourse and terminal.

Defence in the boost phase allows for the destruction of ballistic missiles of all ranges, including intercontinental; however, it is the most difficult to implement. Capture opportunities appear only from one to five minutes after launch. Although the missile is the easiest to detect and track at this stage because the air outlet causes intense light and heat effects, the interceptable warfare agents of the system and sensors must be located at a short distance from the point of its launch. Early 
detection in the boost phase allows for a quick response and interception of the projectile at the beginning of the flight, before the other measures are launched. It also prevents the head from reaching the speed necessary to accurately identify the intended purpose. To enable global protection and defence against more lethal charges, the ability to capture a projectile near its launch site is always more beneficial than attempting to capture a missile closer to its target.

The midcourse phase carries the greatest opportunity to intercept the fired rocket. At this point, the missile moves due to the force of inertia, so it follows a more predictable path. In this phase, the defence has much more time to intercept than in the boost phase, but it also has many more tasks to do. Before capturing the target, it is necessary to recognise all objects released by the carrier, including the warheads, false warheads, balloons and rocket debris. Incorrect recognition may result in a shot to an object that is not the main target. Unfortunately, a longer period in space also gives the attacker more chances to use remedies against the defence system. The U.S approach to ballistic missile defence emphasises interception above the atmosphere, the longest portion of an ICBM warhead's trajectory. Unfortunately, interception can be made particularly difficult here, posing high technical hurdles to success. Due to the absence of air resistance, lightweight countermeasures can be deployed that are indistinguishable from the warhead or can conceal its exact location from the defender's detection systems.

The last possibility of destroying an enemy projectile is its terminal phase. It is very short and starts when the missile re-enters the atmosphere. Intercepting the head during this phase is difficult and least desirable because of the small margin of error, because the destruction of the projectile occurs near the intended target. Defence systems designed for this phase are the most effective in protecting dislocation sites of troops, ports or airports.

The concept of multilayered defence provides many possibilities of capturing the same target, which significantly increases the chances of its destruction. Defence in each layer is able to destroy the missile completely independently; therefore, the survivability of a ballistic missile or warhead is the product of its survival in each layer separately. It can therefore be concluded that a three-tier defence may allow only a few ballistic missiles to break through the entire system. However, to ensure effective multilayered defence, the following conditions must be met in each separate layer: 
- fast detection of the attack, determination of the probable targets of the attacking missiles;

- recognition of misleading purposes and devices;

- targeting and tracking with the high accuracy required by the means to control them;

- supplying sufficient energy to the target in a proper way to destroy it;

- damage assessment and re-identified and distinguished from those that were not destroyed, as well as drawing conclusions from unsuccessful damage.

Multilayered defence brings many benefits - including various ways to engage and use multiple technologies. This system receives the initiative of the attacking party allowing the use of its own strategy and mechanisms. However, the disadvantage of the system is that the layers are not completely independent of each other. Any attacking ballistic missile or warhead must overcome each of the three layers in a set order, so the effectiveness of defence in each layer will affect the defence effectiveness in the next layer. If the first layer passes the ballistic missile, then the next layer will have to eliminate one more target. Moreover, if one missile avoids interception in a given layer, it can be concluded that the circumstances will also be favorable for the next one, which may imply the buildup of leaks in individual layers. This means that failure in the early phases of defence may cause the entire system to collapse. However, due to ongoing work on improving multilayered defence, these issues and difficulties can be overcome by developing technology and system architecture during its further evolution (United States of America Congress 2002).

\section{Components of the BMD system}

Because ballistic missiles have different ranges, speeds, sizes and characteristics, missile defence is an integrated, layered system whose architecture includes:

- network sensors (including space-based), as well as terrestrial and marine detection radars and tracking of targets;

- ground and sea-based capture missiles to destroy ballistic missiles using direct collision force, known as "hit-to-kill" technology or fragmentation warhead; 
- command, control, battlefield management and communications network that provide the operational commander with the necessary connections between sensors and interceptor missiles.

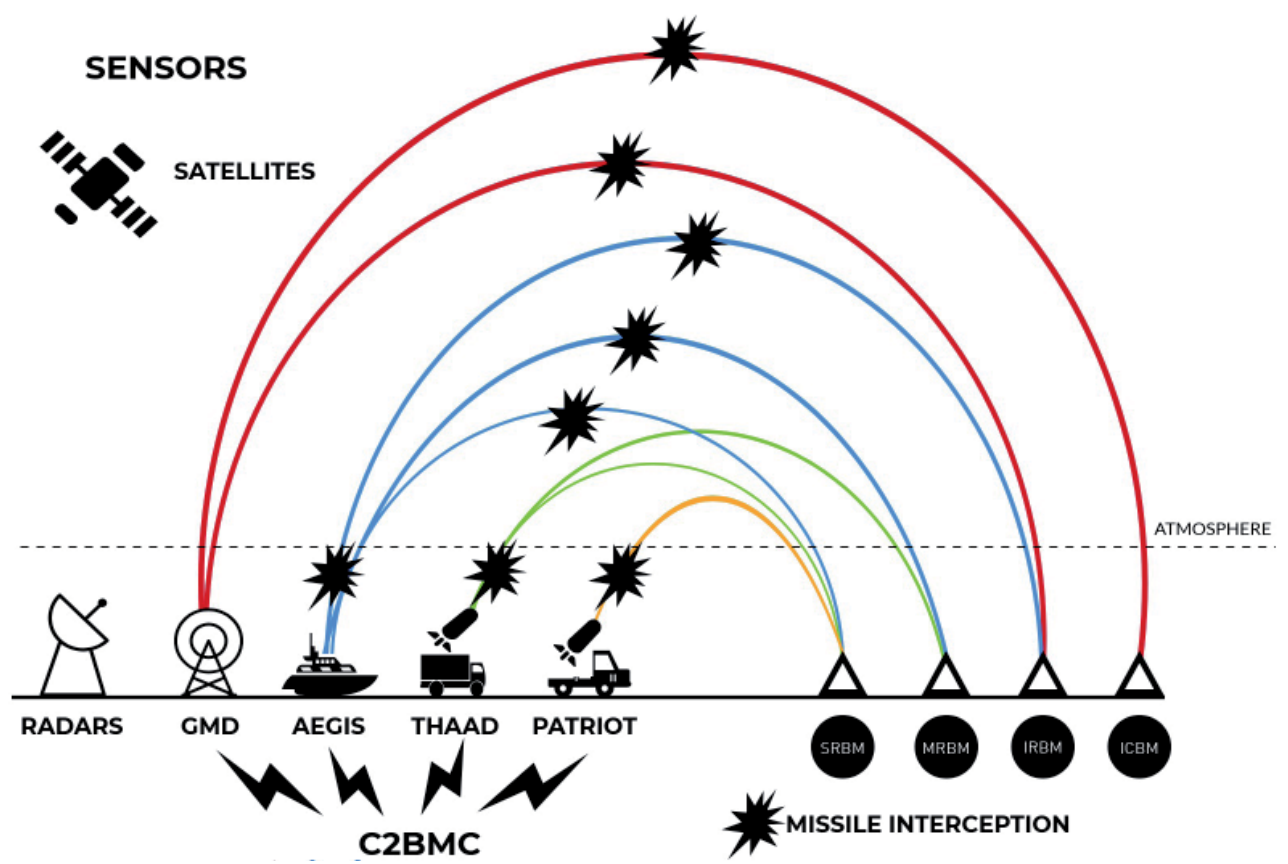

Source: own elaboration.

Figure 3. Components of the BMD system

One of the most important elements of the BMD system is the sensory system, which allows a hostile rocket to be located in advance. Effective multilayered protection includes a wide range of sensors for detecting and tracking threatening missiles in all phases of their flight. Satellites and a whole group of land and sea radars provide sensor coverage almost all over the globe (Jankowski 2012). The first component of the sensor system is the Upgraded Early Warning Radar. UEWRs provide early detection and precise tracking of incoming ballistic missiles, as well as fast and accurate identification of threatening objects in comparison to those that are not hazardous. The UEWR is a key sensor of the BMD system that supports capturing dangerous ballistic missiles above the atmosphere and far from their intended targets while simultaneously carrying out the early warning mission. The UEWRs are strategically located in the bases around the United States and 
in allied bases. Currently, the BMD system includes radars located at the Beale base of air forces in California, at the Royal Air Force base in Fylingdales in Great Britain and at the Thule air base in Greenland. They have two (Beale, Thule) or three (Fylingdales) antennas observing airspace with a beam controlled in the 120 degree range and up to 3000 miles $(4800 \mathrm{~km})$. The location of these radars aims to provide full coverage and allow early warning of any upcoming rocket threats, regardless of where they originate. Cobra Dane (AN/FPS-108) radar, located at Eareckson Air Station in Alaska, fulfills a function similar to the UEWR. It has one antenna with a beam controlled in a range of 136 degrees, observing objects in the L band for up to 2000 miles (3,200 km). Cobra Dane detects tracks and classifies airborne data, of a quality that allows indication of targets for the BMD system, launching rockets intercepting or updating their courses. The next sensors are mobile AN/TPY-2 radars. These are devices operating in the high resolution $\mathrm{X}$-band. They can track all classes of ballistic missiles and identify small objects over long distances. They enable the detection of ballistic missiles at an early stage of flight and provide precise information about the trajectory. Five AN/TPY-2 radars work as midcourse phase sensors to detect, track and differentiate targets and fire control of THAAD interceptor missiles. The other five act as a sensor located close to a potential threat and provide data on ballistic missiles in the early phase of their flight to the BMDS. They are located on the territory of allies in Israel, Japan and Turkey. The radar in Turkey is part of the first phase of the EPAA (Missile Defence Advocacy Alliance 2018b). Another type of sensor is the AN/SPY-1 radar, which is a key element of the AEGIS missile defence system at sea and on land. It was originally designed as an air defence system, but has been improved to be able to act as a missile defence. The passive electronic scanning system SPY-1 is computer controlled, using four complementary antennas to provide full 360 degree coverage. It operates in the S-band and is multifunctional phase-based radar capable of searching, automatic detection, transition to tracking, tracking of air and surface targets and support for missiles. At present, there are 33 radars of this type on the sea, 5 on cruisers and 28 on destroyers. On land, there is currently one such radar located at a base in Romania, and the construction of another, located in Poland, is in progress. Another type of marine radar is SBX, working in the $\mathrm{X}$ band and installed on the adapted mobile oil platform. It is located in the Pacific Ocean and used both during flight tests and BMD system tests, as well as a sensor providing data on possible hazards passing over the Pacific Ocean, 
separated by up to 2,500 miles. Among the sensors are also those located in space. The first of these is the Space Tracking and Surveillance System, consisting of two satellites placed in $1350 \mathrm{~km}$ orbit from Earth. They have visible and infrared wavelength sensors. Their primary goal is to provide accurate information on the position of ballistic warheads and their transfer to BMD, GMD missiles and AEGIS ships. They can also track missiles in all three phases of the flight, transfer data to other systems so that the missile could be shot down. The second of the space components is a group of SBIRS satellites designed to provide global surveillance capabilities in four key mission areas: missile defence, anti-missile warnings, technical intelligence and combat intelligence. SBIRS consists of many satellites and loads on a geosynchronous Earth orbit and a highly elliptical orbit, as well as terrestrial equipment and software (Fundacja im. Kazimierza Pułaskiego 2016).

The boost phase, when the opponent's rocket is still above its territory, is the biggest challenge for the missile defence system. Measures designed to destroy the projectile during its launch phase must be precise enough to use as much as possible a few minutes before the rocket enters the space. Currently, none of the technologies included in the BMD system performs the task of destroying enemy missiles in the boost phase. High hopes associated with the KEI program of missiles launching from the naval launchers on Aegis BMD type CG (X), as well as ground-based car launchers and the ABL system, i.e. a Boeing 747 modified light aircraft device emitting a strong beam of chemical laser light towards the rocket, vanished with the end of these programmes in 2009 and 2012 respectively (Jankowski 2012). Currently, MDA plans to develop and test several new technologies designed to capture and destroy ballistic missiles during this phase, paying particular attention to greater flexibility and precise targeting capabilities. UAVs and already existing cosmic resources for their protection are planned to be used. Thanks to this, the SM-3 missile involvement zone could also be extended to destroy missiles in the boost phase.

The US anti-missile system is created with the assumption that hostile ballistic missiles are the most vulnerable to destruction in the midcourse phase of their flight, and therefore the measures to combat missiles are being expanded the most in this phase. The key element is Ground-based Midcourse Defence, along with GBI rockets. This component is aimed at combating intermediate missiles and the intercontinental range in their flight outside the atmosphere. GBI are 
three-stage solid fuel rockets that destroy targets with the Exoatmospheric Kill Vehicle. The head has its own homing system with infrared sensors and a communication system with the command centre. Silos with GBI rockets, in a total of 44 pieces, are found in Alaska, Fort Greely and the Vandenberg Air Force base in California, while their firing is controlled from bases in Alaska and Colorado. Another integral element of the missile defence system is the AEGIS maritime and land version. Aegis Afloat is equipped with over 30 destroyers and US Navy cruisers and a family of SM interceptors. The system has a dual function of regional and strategic defence. Regional defence consists in combating shortand medium-range ballistic missiles in their central and terminal phase of flight using the SM-3, SM-2 Block IV missile group and the currently implemented SM-6 Dual I/II. Strategic national defence objectives are achieved by collecting radar data and transferring it to other BMD sensors, rockets intercepting the GMD system and other Aegis ships. The deployment of warships equipped with the Aegis system in the Mediterranean is part of the first phase of the EPAA project, which is the United States' contribution to NATO's missile defence system. Of all ships equipped with the AEGIS system, only ten of them fly the flag of the USA, the others belong to its allies: Australia, Japan, South Korea, Spain and Norway. The land-based variant of the Aegis Ashore system was designed to protect US troops and allies in Europe from a ballistic attack from the Middle East. Under the second and third stage of the EPAA programme, at the bases in Romania and Poland, 24 SM-3 IB and SM-3 IIA interceptor missiles with short- to mediumrange targets are to be deployed. The test system complex is located on the PMRF training ground (Arms Control Association 2018).

Elements of the anti-missile shield intended for the destruction of ballistic missiles in the terminal phase of their flight must be characterised by their mobility and a lot of precision and speed of action. In addition to the marine component Aegis Afloat, the main component of the system for this phase is the THAAD component. This mobile system fights ballistic missiles in their terminal phase of the flight, both in space and after returning the warhead to the atmosphere. The missiles are destroyed kinetically at high altitudes using the "hit-to-kill" technology, which minimises the threat associated with warheads containing weapons of mass destruction. Currently, seven THAAD mobile batteries are in service with 144 capture rockets of the same name. Each battery consists of several launchers with eight missiles, AN/TPY-2 radar, fire control station, auxiliary elements and 
spare rockets. The lowest and at the same time the best tested layer of the BMD system is formed by Patriot batteries using PAC-3 rockets. The Patriot missile defence system is a ground-based, mobile missile capture system used by the United States and many other countries. The Patriot system detects tracks and uses UAVs, self-propelling missiles and short-range or tactical ballistic missiles. Patriot missile systems were tested in combat operations in the Middle East during the Desert Storm and Iraqi Freedom operations. Today, the Patriot antiaircraft and missile defence system is being implemented by the United States and its partners and allies around the world. In the armed forces of 13 countries, including Germany, Israel and the Netherlands, there are 43 battalions of this system with over 220 fire bands and over 1,100 launchers. Thus, the Patriot system serves as the last line of defence against ballistic attack (Missile Defense Advocacy Alliance 2016).

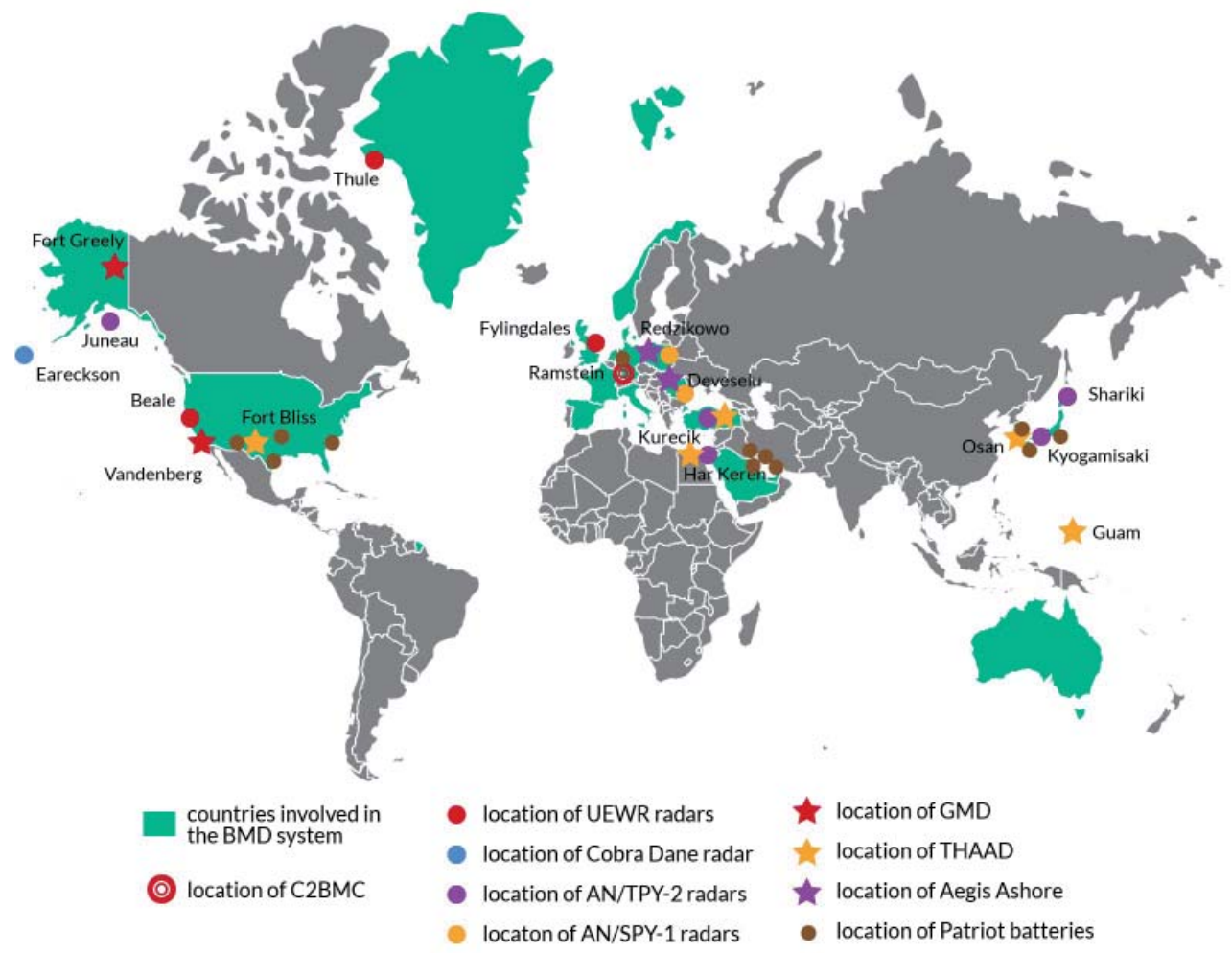

Source: own elaboration.

Figure 4. Locations of land components of the BMD system 
The element that integrates all components of the BMD system is Command and Control, Battle Management and Communication. It enables decision makers to view all sensors and manage real-time means of destruction. It creates a single, integrated image of anti-ballistic defence, ultimately combining data from all elements connected to it. C2BMC is responsible for integrating individual components to create a global, multilayered missile defence system capable of identifying, tracking and capturing missile threats in all phases of flight. The system is also used to plan missile defence activities, situational awareness during tasks, software management to calculate missile trajectory, sensors management, data exchange and network management (Lockheed Martin 2018). The C2BMC system is implemented on the STRATCOM, NORTHCOM, EUCOM, PACOM, CENTCOM platforms, in numerous Army, Air and Missile Defence Commands, Air and Space Operations Centres, and other supporting warfighter organisations. C2BMC is also crucial for regional BMD initiatives such as EPAA because it integrates different components of missile defence and sensors in large areas. Integration provided by C2BMC allows sensors such as AN/TPY-2 in Turkey to warn and activate BMD systems in Europe that, using data provided by $\mathrm{C} 2 \mathrm{BMC}$, can more effectively identify, track and capture threatening ballistic missiles. Antimissile defence systems integrated with C2BMC include GMD, Aegis Ashore and Afloat components, THAAD, AN/TPY-2, SBX, UEWR and SBIRS radars (Missile Defence Advocacy Alliance 2018a). The entire American missile defence system has more than $70 \mathrm{C} 2 \mathrm{BMC}$ workplaces deployed, while the European component is located at the German base in Ramstein.

\section{Conclusion}

In the short term, the development of the BMD system will focus on the quantitative increase of equipment and the evolutionary upgrades of subsystems. At the same time, taking into account the high costs of currently used systems and kinetic missiles, innovative alternative technologies are being developed. The long-term goal of BMD is the deployment of cost-effective energy systems directed at long-distance UAVs flying at high altitudes. By means of a laser beam, they would destroy the ICBM rocket in the boost phase of its flight over the territory of the enemy. MDA intends to develop a laser demonstrator by 2020 
or 2021 and implement the capacity by 2025 . The modernisation of the existing Patriot batteries is also planned. In the following years, it is planned to increase the effectiveness of defence against tactical ballistic missiles and to implement protection against anti-radio warfare measures. Work is also underway to create a technology that would destroy enemy missiles before they launch a rocket. As technology allows new threats to evolve, the possibilities of using modern missile defence to protect the US and its allies are also expanding. MDA focuses its efforts on ensuring the BMD system stays ahead of the development of foreign rocket threats (Arms Control Association 2018). Solutions that were considered unrealistic decades ago are rapidly becoming feasible.

There is no doubt that BMDS is a very important project for the security of the United States and its allies in Europe and beyond. System development is a big challenge for MDA and its cooperating producers. Higher and higher technological requirements require more and more modern solutions and searching for new solutions for existing problems. Today, only one system in place seems to be capable of defending the US against ICBMs: GMD based in Fort Greely, Alaska, and Vandenberg Air Force Base, California. That is why support for missile defence should continue at least at this pace.

Continuous proliferation of nuclear weapons and the evolution of missile technology mean that the threat of strategic attacks by warheads carrying weapons of mass destruction ceases to be a distant threat. Sound defence policy demands solutions for the worst-case scenarios. Unchecked, nations possessing ICBMs have the ability to put military and civilian targets at risk located in the homeland. Even in the most ideal conditions, both Iran and North Korea have a long history of reneging on international agreements. Indeed, the most alarming scenario would be unconstrained nations in possession of nuclear weapons, and the means to deliver them. For this reason, efforts of the US and NATO member states focus on developing missile defence. It is worth emphasising, however, that missile defence is not and will not be a panacea for all threats of the modern world. It is one of the available strategic instruments in relation to the specific type of threats, such as ballistic missiles. There is a whole group of complementary strategic tools today, such as activities under the Treaty on the Non-Proliferation of Nuclear Weapons or counter-proliferation operations, deterrence or preventive operations. However, it should be remembered that the development of missile defence is 
an objective phenomenon that fits into the entire history of the development of armed struggle measures and will undoubtedly be one of the essential elements of the future global, regional and national security systems in the coming decades. This is a natural response to asymmetric nuclear and missile threats (Koziej 2007). Along with economic pressure and diplomacy, the United States and their allies must fully utilise their considerable resources to ensure the country is safe from the threat of ballistic missiles. While the world remains hopeful for a diplomatic solution to a pressing threat, the devastation that could be caused by ballistic missiles is too great a risk to ignore.

\section{References}

Arms Control Association, 2018. U.S. Missile Defense Programs at a Glance [online] Available from: www.armscontrol.org/factsheets/usmissiledefense\#nextgen [Accessed 8 Jun 2018].

Arms Control Association, 2017. The European Phased Adaptive Approach at a Glance [online] Available from: www.armscontrol.org/factsheets/Phasedadaptiveapproach [Accessed 18 May 2018].

Carter, A. and Schwartz, D., 1984. Ballistic missile defense. Washington Brookings Institution, Washington.

Ciastoń, R., 2007. Tarcza. Stosunki Międzynarodowe, 48/49

Dobrosielski, M., 1973. Problemy współczesnych stosunków międzynarodowych. Sprawy Międzynarodowe, 11, 20-21.

Encyklopedia Techniki Wojskowej, 1978. Wydawnictwo Ministerstwa Obrony Narodowej, Warsaw.

Fundacja im. Kazimierza Pułaskiego, 2016. Analiza: Obrona przeciwrakietowa Stanów Zjednoczonych [online] Available from: https://pulaski.pl/obrona-przeciwrakietowastanow-zjednoczonych/ [Accessed 13 Jun 2018].

Global Security, 2017. Weapons of Mass Destruction: Ballistic Missile Basics [online] Available from: www.globalsecurity.org/wmd/intro/bm-basics.htm [Accessed 7 MAY 2018].

Heurlin, B., 2005. Missile defence: international, regional and national implications. Routledge, New York.

Hildreth, S.A., 2009. Long-Range Ballistic Missile Defense in Europe. DIANE Publishing, Washington.

Hołdak, K., 2007. Polska w amerykańskim systemie obrony przeciwrakietowej. Biblioteka "Bezpieczeństwa Narodowego", 1, 20-24. 
Jankowski, D., 2011. Amerykański system obrony przeciwrakietowej. Wydawnictwo Adam Marszałek, Toruń.

Kaczmarski, M., 2004. Obrona przeciwrakietowa Stanów Zjednoczonych i jej implikacje międzynarodowe. Wydawnictwo Adam Marszałek, Toruń.

Koziej, S., 2007. Tarcza antyrakietowa - dylematy strategiczne. Znak, 4, 18-20.

Kwasek, T., 2016. Aegis Ashore - element amerykańskiej tarczy antyrakietowej w Polsce. Nowa Technika Wojskowa, 6, 9-16.

LaGrone, S., 2016. Aegis Ashore Site in Romania Declared Operational. USNI News [online] Available from: https://news.usni.org/2016/05/12/aegis-ashore-site-inromania-declared-operational [Accessed 29 Jun 2018].

Lockheed Martin, 2018. Command and Control, Battle Management, and Communications (C2BMC) System [online] Available from:

www.lockheedmartin.com/us/products/c2bmc.html [Accessed 13 Jun 2018].

Missile Defense Advocacy Alliance, 2016. An Overview of Current and Future BMD Capabilities. U.S. Ballistic Missile Defense, Alexandria.

Missile Defense Advocacy Alliance, 2018a. U.S. Deployed Intercept Systems [online] Available from: http://missiledefenseadvocacy.org/missile-defense-systems-2/ missile-defense-systems/u-s-deployed-intercept-systems/ [Accessed 13 Jun 2018].

Missile Defense Advocacy Alliance, 2018b.U.S. Deployed Sensor Systems [online] Available from: http://missiledefenseadvocacy.org/missile-defense-systems-2/missile-defensesystems/u-s-deployed-sensor-systems/ [Accessed 13 Jun 2018].

Missile Defense Agency, 2018. The Threat [online] Available from: www.mda.mil/mdalink/ html/threat.html [Accessed 20 May 2018].

North Atlantic Treaty Organization, 2016. NATO Ballistic Missile Defence [online] Available from: https://www. nato.int/nato_static_fl2014/assets/pdf/pdf_2016_07/20160_6

301607-factsheet-bmd-en.pdf [Accessed 3 Jun 2018].

Pacholski, P., 2003 System obrony przeciwrakietowej. Rozwój i znaczenie. Wydawnictwo Adam Marszałek, Warsaw.

Raabe, S., 2008. Amerykańska tarcza antyrakietowa w Europie: konieczność, warunki, akceptacja. Fundacja Konrada Adenauera, Warsaw.

Remarks by the President to Students and Faculty at National Defense University, 2001. [online] Available from: http://www.presidency.ucsb.edu/ws/?pid=45568 [Accessed 20 May 2018].

Scheffran, J., 2007. Missiles in conflict: the issue of missiles in all its complexity. Disarmament Forum, 1, pp. 60-75.

Smith, D., 2000. A Brief History of "Missiles" and Ballistic Missile Defense. National Missile Defense. What Does It Mean? A CDI Issue Brief, pp. 10-14.

The White House, 2018. National Security and Defense [online] Available from: https:// www.whitehouse.gov/issues/national-security-defense/ [Accessed 20 May 2018]. 
Treaty between the United States of America and the Union of Soviet Socialist Republics on the Limitation of Anti-Ballistic Missile Systems, 1972. [online] Available from: https://www.state.gov/t/isn/trty/16332.htm [Accessed 20 May 2018].

Turczyński, P., 2012. Amerykańskie koncepcje tarczy antyrakietowej w Europie. Poltext, Warsaw.

United States of America Congress, 2002. Ballistic Missile Defense Technologies. University Press of Pacific, Honolulu.

Wilkening, D., 2005. Ballistic-Missile Defence and Strategic Stability. Routledge, New York. 


\section{Appendix}

\section{Abbreviations}

ABL - Airborne Lasers

ABM - Anti-Ballistic Missile Treaty

BAMBI - Ballistic Missile Boost Intercept

BMD - Ballistic Missile Defence

BMDS - Ballistic Missile Defence System

C2BMC - Command and Control, Battle Management and Communication

DEW - Directed Energy Weapons

EPAA - European Phased Adaptive Approach

GBD - Ground-based Midcourse Defence

GBI - Ground Based Interceptor

GBR - Ground Based Radar

GMD - Ground-based Midcourse Defence

GPALS - Global Protection Against Limited Strikes

ICBM - Intercontinental Ballistic Missiles

IRBM - Intermediate-Range Ballistic Missiles

KEI - Kinetic Energy Interceptors

MD - Missile Defence

MDA - Missile Defence Agency

MDS - Missile Defence Segment

MRBM - Medium-Range Ballistic Missiles

NMD - National Missile Defence 
PMRF - Pacific Missile Range Facility

SBIRS - Space-Based Infrared System

SDI - Strategic Defense Initiative

SRBM - Short-Range Ballistic Missile

THAAD - Terminal High Altitude Area Defence

TMD - Theater Missile Defence

UAV - Unmanned Aerial Vehicle

UEWR - Upgraded Early Warning Radar

XBR - X-Band Radar 